\title{
ПЕРСПЕКТИВНІ ПРАКТИКИ ВЗАЕМОДІЇ УНІВЕРСИТЕТУ 3 ГРОМАДОЮ, БІЗНЕСОМ І ВЛАДОЮ ЯК ОСНОВА ЙОГО КОНКУРЕНТОСПРОМОЖНОСТІ
}

Наукова доповідь на методологічному семінарі НАПН України «Шляхи і механізми підвищення конкурентоспроможності університетів України» 19 листопада 2020 p.

https://doi.org/10.37472/2707-305X-2020-2-2-13-8

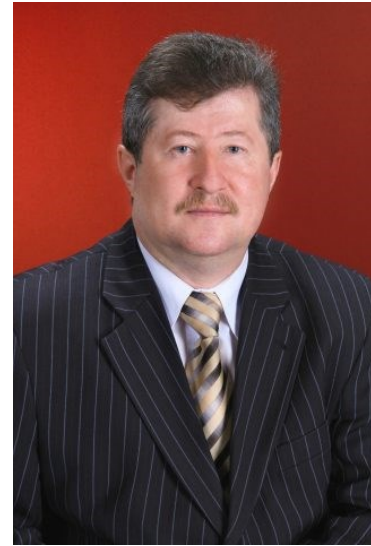

СОЛОНЕНКО АНатолій Миколайович

доктор біологічних наук, професор, ректор

Мелітопольського державного педагогічного

університету імені Богдана Хмельницького,

м. Мелітополь, Україна

(iD) $\triangle$

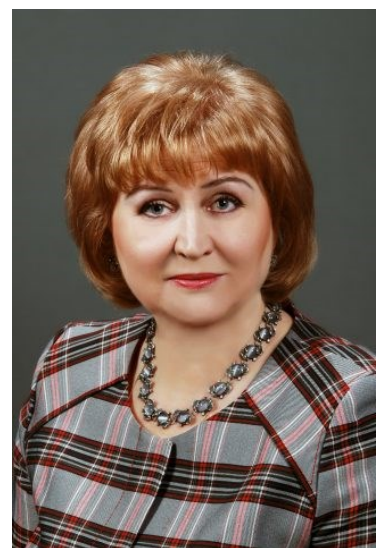

ФЕДОРОВА Олена Василівна

кандидат педагогічних наук, доцент, директор

Навчально-наукового інституту соціально-педагогічної та мистецької освіти Мелітопольського державного педагогічного університету імені Богдана

Хмельницького, м. Мелітополь, Україна

(iD) $D$

СЕГЕДА Наталя Анатоліївна доктор педагогічних наук, професор, завідувач каферери теорії і методики музичної освіти та хореографії Мелітопольського державного педагогічного університету імені Богдана Хмельницького, м. Мелітополь, Україна
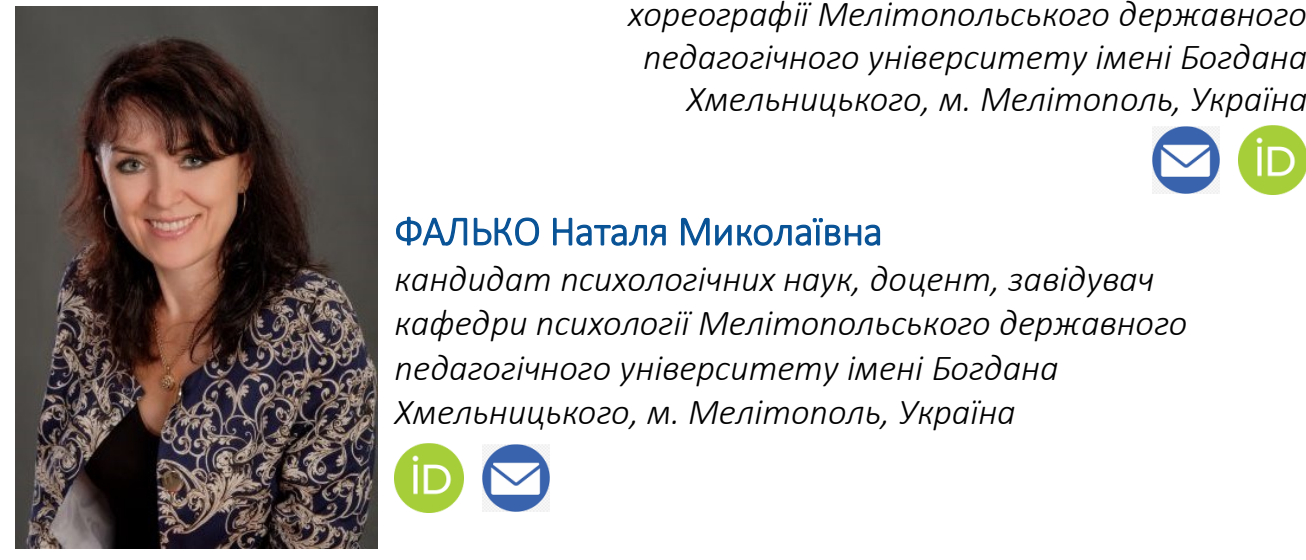

ФАЛЬКО Наталя Миколаївна

кандидат психологічних наук, доцент, завідувач

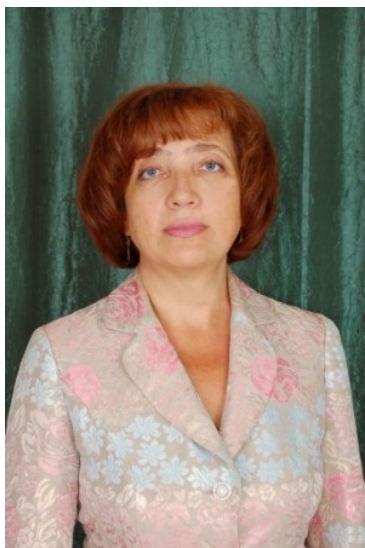

кафедри психології Мелітопольського державного

педагогічного університету імені Богдана

Хмельницького, м. Мелітополь, Україна 
Анотація. У доповіді пропонується стислий огляд досвіду Мелітопольського державного педагогічного університету імені Богдана Хмельницького у розробці стратегічних траєкторій розвитку університету та шляхів їх реалізації з метою успішної конкуренції на ринку освітніх послуг. у доповіді подано практичні результати системної діяльності університету у сферах суспільного життя, бізнесу, влади, взаємодія з якими розкриває перспективи конкурентоспроможності та самоствердження в освітньому просторі України та за ї̈ межами. Зокрема, розкрито зміст критеріїв, що уможливлюють продуктивну взаємодію з громадою, бізнесом і владою: успішні конкурентоспроможні випускники; прозорість вступної компанії; різноманітність освітніх програм; успішна акредитація освітніх програм; реалізація концепції освіти впродовж життя; забезпечення неформальної освіти; розробка і введення сертифікаційних програм і цілісної програми професійного зростання викладачів університету; започаткування спільної з НАПн України широкомаситабної просвітницької діяльності у формі відкритого освітнього простору Методичної майстерні вчителя Нової української школи; співпраця з органами місцевого самоврядування та громадою; пошук і налагодження партнерських відносин з вдалими підприємиями регіону; активність науковців у розробці соціально актуальних і економічно раціональних для регіону програм, позитивна динаміка рейтингових показників університету.

Ключові слова: конкурентоспроможність; якість освіти; громада; бізнес; влада; взаємодія; освіта впродовж життя; науковий продукт.

Громадські очікування від університетської освітньої, наукової спільноти залишаються незмінними: університети - це генератори прогресивних змін і лідери суспільного поступу. Це стосується як продукування і поширення інноваційних технологій, так і народження та обґрунтування перспективних ідей і цінностей, ефективних в організації людського буття сьогодні та в майбутньому. Із сучасними закладами вищої освіти суспільство пов'язує подальший стійкий економічний розвиток.

У Стратегії розвитку вищої освіти України на 2021-2031 роки наводиться статистика, за якою станом на початок 2019/2020 н.р. кількість університетів, інститутів, академій зросла порівняно 3 2014/2015 н.р. на 1,4 \% (до 281). У цьому документі зазначено, що за індикатором «міцності системи», який оцінює загальну міцність національної системи на основі результатів у міжнародних рейтингах, Україна отримала оцінку 16,1 зі 100, тоді, як Велика Британія - 98,7, Німеччина 94,3 (МОН України, 2020, с. 9).

Існує суперечність між розширенням ринку освітніх послуг та їх конкурентоспроможністю як на світовому, так і на національному рівнях. Об'єктивні освітні та економічні тенденції мотивують університети шукати стратегії самоствердження як успішних провайдерів освітніх послуг.

Питання якості освіти перебуває в єдиній площині з питаннями конкурентоспроможності, їх зв'язок закономірний. Отже, забезпечення якості освіти для нашого університету $є$ визначальним. Якість освіти може трактуватись як широке поняття, водночас у діяльності Мелітопольського державного педагогічного університету імені Богдана Хмельницького (далі - МДПУ імені Богдана Хмельницького) воно має конкрет- не наповнення, яке ми подаємо в стислому огляді практичного досвіду, що засвідчує перспективи конкурентоспроможності. Зокрема, одним із важливих індикаторів якісної освіти є успішні конкурентоспроможні випускники. Саме тому в університеті приділяється велика увага профорієнтаційній роботі. 3 цією метою створено Раду випускників за участі осіб, які не тільки закінчили МдПу імені Богдана Хмельницького, а й мають значні досягнення в професійній сфері і гідно підтримують реноме університету далеко за межами України.

Прозорість вступної компанії. Прийняття студентів на навчання - питання не кількості абітурієнтів, а принципу створення людиноцентрованого середовища, в якому особистість максимально зможе реалізувати свій потенціал. Перше, на чому робиться акцент в процесі вступної компанії в МДПУ імені Богдана Хмельницького - максимальна прозорість, адже ми розуміємо, що корупція у таких питаннях неминуче погіршує якість студентського складу, а отже, й призводить до втрати репутації закладу, гіршого працевлаштування випускників. Прозора політика приймальної компанії уже має ефективні результати, що відбивається на позитивній динаміці контингенту здобувачів вищої освіти в університеті.

Різноманітність освітніх програм. В університеті відбувається підготовка за 37 спеціальностями. Освітні програми демонструють відданість як класичним напрямам (наприклад, ОПП «Середня освіта. Математика», «Дошкільна освіта. Початкова освіта», «Середня освіта. Музичне мистецтво», «Хореографія» та ін.), так і започаткування сучасних і актуальних програм («Біологія. Фізична реабілітація»; «Управління станом і 
якістю довкілля» та ін.). Задоволення освітніх інтересів споживачів освітніх послуг визначається на підставі попиту на освітні програми та їх економічної доцільності.

Успішна акредитація освітніх програм. Офіційний «знак якості» освітніх програм університету надається у вигляді їх акредитації. Так, 3 кінця 2019 р. усі подані до Національного агентства із забезпечення якості вищої освіти програми пройшли акредитацію. Зазначимо, що науковопедагогічні працівники нашого університету гідно працюють експертами у галузевих експертних радах Нацагентства.

Реалізація концепції освіти впродовж життя. Забезпечення багаторівневої освіти в університеті реалізується у кілька спектрів. По-перше, це забезпечення неперервної освіти через 44 освітньо-професійні програми рівня бакалавpa, 40 - магістра, п'ять - доктора PhD.

Для забезпечення неформальної освіти в університеті реалізується серія різноманітних сертифікаційних програм і цілісна програма професійного зростання викладачів.

Питання якості освіти перебуває у єдиній площині з питаннями конкурентоспроможності, їх зв'язок закономірний. Пізнаваність університету на ринку освітніх послуг як критерій нашої конкурентоспроможності стала можливою завдяки започаткуванню разом із НАПН України широкомасштабної просвітницької діяльності у формі відкритого освітнього простору Методичної майстерні вчителя Нової української школи. Так, з жовтня 2017 р. нами проведено 78 заходів, на яких відбувалось професійне взаємозбагачення різних фахівців, а для студентів це була нагода поринути в практичну реальність обраної професії. Разом із НАПН України реалізовано науковопрактичні проєкти:

- Всеукраїнська науково-практична конференція 3 міжнародною участю «Особистіснопрофесійний розвиток учителя в умовах реалізації Концепції Нової української школи» (1416 червня 2018 р.);

- II Всеукраїнська науково-практична конференція 3 міжнародною участю «Особистіснопрофесійний розвиток учителя Нової української школи: світові освітні практики, український контекст» (6-7 червня 2019 р.);

- Міжнародна науково-практична конференція «Пріоритетні напрями психологопедагогічного супроводу в освітньому просторі Нової української школи: організація, координа- ція, науково-методичне забезпечення»

(1213 вересня 2019 р.).

Реалізація наукового потенціалу університету останнім часом дає змогу залучати певні кошти і вже помітно чітку тенденцію до постійного прогресу. Взаємодія університету із бізнесом, побудована на основі взаємовигідних відносин для всіх учасників цього процесу, демонструє перспективні результати. Шукаючи конкурентних переваг на ринку, відкриваючи нові напрями діяльності, бізнесмени звертаються до нас, замовляють наукові дослідження, отримують консультації. У такій взаємодії влада не залишається осторонь, а всіляко сприяє нам у пошуку і налагодженні партнерських відносин з успішними підприємцями регіону. Для університету така співпраця, окрім фінансових надходжень, сприяє зростанню якості науки і освіти, відбувається постійний процес модернізації змісту освітніх програм, з'являється стимул до розвитку матеріальнотехнічної бази наукових досліджень і все це циклічно впливає і на всі складові освітнього і наукового середовища закладу.

На державному рівні МДПУ імені Богдана Хмельницького гідно представив нові розробки на XI Міжнародній виставці «Сучасні заклади освіти - 2020», що відбулась 4-6 серпня 2020 р. у м. Києві за участі МОН України та НАПН України. Власні досягнення презентували більше 500 закладів освіти і наукових установ. За результатами рейтингу МДПУ імені Богдана Хмельницького отримав Гран-прі - 2020 у номінації «Лідер міжнародної діяльності». Також університет було нагороджено в тематичному конкурсі в номінації «Упровадження інформаційно-цифрових систем і технологій у навчальній, дослідницькій та інноваційній діяльності закладів освіти». За результатами роботи заклад отримав диплом «За активну участь у презентації досягнень із модернізації національної освіти», а також відзначений сертифікатом якості наукових публікацій.

Успішні університети, що відіграють головну роль у розвитку людського капіталу, є генераторами прогресивних змін і лідерами суспільного поступу. Це стосується як продукування і поширення передових знань та створення на їх основі інноваційних технологій, так і народження та обґрунтування перспективних ідей і цінностей, що ефективні в організації людського буття у сучасних умовах і в майбутньому. Отже, конкурентоспроможність закладу вищої освіти системно пов'язана з наступним стратегічним блоком - 
це співпраця з органами місцевого самовряду вання і громадою.

Стратегія розвитку МДПУ імені Богдана Хмельницького визначає його місію як навчального закладу вищої професійної освіти у спрямуванні діяльності суб'єктів освітнього процесу на розвиток освіти, науки і культури на основі фундаментальних наукових досліджень за широким спектром природничих, гуманітарних та інших напрямів. У Стратегії визначено, що університет повинен стати науковим, освітнім, культурнопросвітницьким центром міста, регіону та країни.

Мелітопольський державний педагогічний університет імені Богдана Хмельницького один з провідних педагогічних закладів вищої освіти України, який демонструє свою активну позицію у реалізації соціальних і культурних проєктів сталого розвитку й становлення громадянського суспільства як на державному, так і на регіональному рівнях, адже має значні напрацювання і ґрунтовну експертно-наукову галузеву базу.

Так, на рівні області ma міста науковопедагогічні працівники університету $€$ членами робочих груп:

- Департаменту соціального захисту населення Запорізької обласної державної адміністрації щодо взаємодії суб'єктів із надання соціальнопсихологічної допомоги особам, демобілізованим з лав Збройних Сил України, Національної Гвардії України, Прикордонної служби України, учасникам АТО та їх сім'ям (наказ Департаменту соціального захисту населення Запорізької обласної державної адміністрації «Про створення координаційної групи щодо взаємодії суб'єктів із надання соціально-психологічної допомоги особам, демобілізованим з лав Збройних Сил України, Національної Гвардії України, Прикордонної служби України, учасникам антитерористичної операції та їх сім'ям» від 25 березня 2015 р. № 50);

- експерименту Всеукраїнського рівня за темою «Система підготовки фахівців соціальної сфери до національно-патріотичного виховання дітей та молоді на засадах соціального партнерства» на базі навчальних закладів Запорізької області у 2017-2022 роках» (наказ Міністерства освіти і науки України від 3 квітня 2018 р. № 313);

- з розробки стратегії розвитку туризму Запорізької області (розпорядження голови Запорізької обласної державної адміністрації від 1 вересня 2020 р. № 382);
- 3 реалізації маркетингової стратегії м. Мелітополя (розпорядження «Про затвердження складу робочої групи з реалізації маркетингової стратегії міста Мелітополя» від 20 листопада 2018 р. № 502-р), експертами та проєктними менеджерами з питань туризму в Агенції розвитку м. Мелітополь;

- проєкту «Містки громадської активності». Освітнє спрямування проведеного картування у рамках реалізації цього проєкту обумовлювалось приєднанням м. Мелітополя Запорізької області у червні 2016 р. до всесвітньої спільноти прогресивних міст, що підписали Пекінську декларацію та задекларували пріоритетом свого розвитку підтримку освіти упродовж життя. Активно долучившись до впровадження концепту Пекінської декларації, Мелітополь став першим містом, яке увійшло до Глобальної мережі ЮНЕСКО «Міст, що навчаються» зі статусом постійного членства у мережі - як в Україні, так і на всьому пострадянському просторі. Після вступу в глобальну мережу ЮНЕСКО у міста з'явилися зобов'язання щодо впровадження політики «навчання протягом життя для всіх» на місцевому рівні;

- проєктної групи з питань туризму Агенції розвитку м. Мелітополь та координаторами діяльності відділу маркетингу та туризму виконавчого комітету ММР30, радниками мера м. Мелітополь з питань інтеркультурності, очолюють різні громадські спілки та центри (Спілка краєзнавців Мелітопольщини, Науково-методичний центр з вивчення нематеріальної культурної спадщини народів Приазов'я тощо).

Вчені університету, керуючись концептом інтеркультурної стратегії, розробленою Програмою Ради Європи «Інтеркультурні міста», у 2014 р. стали ініціаторами розробки Інтеркультурної стратегії міста - нині єдиного подібного документа, прийнятого до виконання міською радою в Україні (затверджено рішенням сесії Мелітопольської міської ради Запорізької області VI скликання «Про затвердження Плану міжкультурної інтеграції міста Мелітополя до 2020 року» від 30 липня 2015 р. № 13). Завдяки належному комплексному науковому супроводу і системному моніторингу соціальних проблем міста міська громада отримала можливість своєчасної оцінки ефективності взаємодії органів самоврядування і національно-культурних товариств, визначати пріоритети у розробці інтеркультурної міської політики з реалізації «Стратегії розвитку міста Мелітополя» та координувати зусилля мерії, 
міських відділів освіти і культури, міської громади та Асоціації національних громад. Аналіз отриманих даних дав підстави для наукового обґрунтування пріоритетного напряму «План міжкультурної інтеграції м. Мелітополя», основна мета якого - працювати разом заради подальшого розвитку інтеркультурного Мелітополя, створюючи умови та нові можливості для динамічного, інклюзивного та по-справжньому інтеркультурного суспільства з участю усіх жителів міста, незалежно від їх етнічного походження, віросповідання, віку, статі чи освіти.

Досліднищькі проєкти інтеркультурної інтеграції м. Мелітополя:

Одним з пріоритетних напрямів реалізації «Плану інтеркультурної інтеграції міста Мелітополя» у 2019 р. було збільшення кількості заходів, спрямованих на зміцнення культурного розмаїття та сприяння міжкультурній взаємодії та діалогу. Слід зазначити, що ефективна співпраця заслуговує особливої уваги, адже це є одним з основних принципів інтеркультурності. Прикладом такої кооперації, яка ґрунтується на проактивному підході, стала плідна проєктна співпраця університету з партнерами:

- Мелітопольською централізованою бібліотечною системою,

- Мелітопольською єврейською общиною,

- Мелітопольським міським краєзнавчим музеєм,

- Центром мексиканської культури «Естрея».

Наприклад, підготовлено та спільно реалізовано:

- проєкти Британської Ради «Активні громадяни» щодо налагодження інтеркультурної співпраці, питання інклюзії та створення простору для розвитку і відпочинку молоді, проблем екології міста, ставлення до безпритульних тварин;

- на базі коворкінг-центру Мелітопольської міської бібліотеки ім. М. Горького «Школи модераторів» проєкт «Муніципальний менеджмент міста Мелітополя» за підтримки німецького товариства міжнародного співробітництва GIZ.

Вчені університету виступили ініціаторами розробок:

- проєкту «Мапи проблем мікрорайонів» із пропозиціями для органів місцевого самоврядування на підставі думки громади. Мапування потреб жителів міста - це один з інструментів, який допомагає візуально та дієво виявити проблему окремого мікрорайону;

- проєкту «Робота культурно-дозвіллєвих закладів і культурне мапування очима мелітопо- льців» 3 пропозиціями для органів місцевого самоврядування на підставі думки громади.

Окреслені практики взаємодії університету 3 бізнесом, владою та громадою демонструють наші конкурентні перспективи, які підтверджуються значними змінами у його позиціях у різноманітних рейтингах. Обрана стратегія дала змогу університету увійти в першу десятку педагогічних закладів України в консолідованому рейтингу.

У 2020 р. МДПУ імені Богдана Хмельницького посів 135-136 місце в консолідованому рейтингу ЗВО України, тоді як у минулому році (2019р.) університет перебував на 187-188 місці (Освіта.uа, 2020а). У новому академічному рейтингу закладів вищої освіти України «Топ-200 Україна» 2020 р. університет посів 84 місце (для порівняння: у 2019 р. - 140 позиція).

У міжнародному рейтингу «Вебометрикс», який ураховує кількість проіндексованих пошуковими системами сторінок сайту закладів освіти, зовнішніх посилань на нього, цитування ресурсу, а також кількість завантажених на сайт файлів, МДПУ імені Богдана Хмельницького посідає 58 місце серед 320 ЗВО України, 6317 місце серед ЗВО світу, 1688 місце серед університетів Європи (Ranking Web of Universities, 2020a).

Університет продовжує демонструвати високий рівень діяльності та присутності в інтернетпросторі, а також забезпечує максимальну доступність інформації для усіх користувачів Інтернету, посівши 13 місце (у попередній версії рейтингу МДПУ імені Богдана Хмельницького посідав 23 місце) за показником «Impact Rank» (зовнішні посилання на сайт університету) серед 320 закладів вищої освіти (Ranking Web of Universities, 2020b).

В одному з підрейтингів - «Кращі педагогічні заклади вищої освіти України» - наш університет увійшов у ТОП-10 найкращих педагогічних 3ВО зайняв 10 місце (Освіта.uа, 2020b). У підрейтингу закладів вищої освіти Запоріжжя та Запорізької області наш університет посів п'яте місце (Освіта.иа, 2020c).

Значні напрацювання і ґрунтовна експертнонаукова галузева база засвідчує, що МДПу імені Богдана Хмельницького - один із провідних педагогічних ЗВО України, який демонструє активну позицію у реалізації соціальних і культурних проєктів сталого розвитку й становлення громадянського суспільства як на державному, так і на регіональному рівнях. 
Завершуючи стислий огляд перспективних практик взаємодії МДПУ імені Богдана Хмельницького з бізнесом, громадою і владою, наголошу$\epsilon м о$, що запропоновані та реалізовані шляхи дають змогу вітчизняним педагогічним університетам розробляти інноваційні напрями та витримувати конкурентну боротьбу, впевнено себе почувати науковим, освітнім, культурнопросвітницьким центром міста, регіону та країни.

\section{СПИСОК ВИКОРИСТАНИХ ДЖЕРЕЛ}

Мелітопольський державний педагогічний універсиmет імені Богдана Хмельницького. (n.d.). https:// mdpu.org.ua/
Міністерство освіти і науки України. (2020, 25 вересня). Стратегія розвитку вищої освіти в Україні на 2021-2031 роки. https://cutt.ly/fjrLmEd

Освіта.иа. (2020а, 10 серпня). Консолідований рейтинг вищів України 2020 року. https://osvita.ua/ vnz/rating/51741/

Освіта.иа. (2020b, 10 серпня). Кращі педагогічні заклади вищої освіти України. https://osvita.ua/ vnz/rating/42227/

Освіта.иа. (2020с, 10 серпня). Рейтинг вищих навчальних закладів запоріжжя. http://osvita.ua/vnz/ rating/45553/

Ranking Web of Universities. (2020a, July). World. https://www.webometrics.info/en/world

Ranking Web of Universities. (2020b, July). Ukraine. https://cutt.ly/TjrLak2

PROSPECTIVE PRACTICES OF THE UNIVERSITY'S COLLABORATION WITH THE COMMUNITY, BUSINESS AND GOVERNMENT AS THE BASIS FOR ITS COMPETITIVENESS

Scientific report at the methodological seminar of the National Academy of Educational Sciences of Ukraine

"Ways and Mechanisms of Increasing the Competitiveness of Universities", November 19, 2020

Anatolii Solonenko

DSc in Biology, Professor, Rector, Bohdan Khmelnytskyi

Melitopol State Pedagogical University, Melitopol, Ukraine

Iryna Maltseva

DSc in Biology, Professor, First Vice-Rector, Bohdan Khmelnytskyi

Melitopol State Pedagogical University, Melitopol, Ukraine

Olena Fedorova

PhD in Pedagogy, Associate Professor, Director of the Training and Scientific Institute for Socially Pedagogical and Art Education, Bohdan Khmelnytskyi Melitopol State Pedagogical University, Melitopol, Ukraine Natalia Seheda

DSc in Pedagogy, Professor, Head of the Department of Theory and Methods of Music Education and

Choreography, Bohdan Khmelnytskyi Melitopol State Pedagogical University, Melitopol, Ukraine

Natalia Falko

PhD in Psychology, Associate Professor, Head of the Department of Psychology,

Bohdan Khmelnytskyi Melitopol State Pedagogical University, Melitopol, Ukraine

\begin{abstract}
The report presents a short overview of Bohdan Khmelnytskyi Melitopol State Pedagogical University experience of working out the strategic vectors of university development and the ways of its implementing aimed at the successful competitiveness in the market of educational services. It reveals the practical results of systemic activity of the university in the spheres of social life, business, government, collaboration with which opens the prospects of competitiveness and self-empowerment in the educational space of Ukraine and beyond its borders. In particular, the criteria enabling the productive cooperation with the society, business and government are defined: successful competitive graduates; transparency of the university admission process; variety of educational programmes; successful accreditation of educational programs; realisation of the lifelong leaning concept; providing non-formal education; development and implementing the certification programmes and the integral programme of professional excellence for university teachers; launching of joint with the National Academy of Educational Sciences of Ukraine large-scale educational activities in the form of open educational space - Methodical Workshop of the New Ukrainian School Teacher; collaboration with local authorities and the community; searching and building partnerships with successful entrepreneurs of the region; researchers' activity in developing the socially relevant and economically rational programmes for the region; positive dynamics of rating indicators of the university.
\end{abstract}

Keywords: competitiveness; quality of education; community; business; government; collaboration; lifelong leaning; research results. 